\title{
Volatility in Crude Oil Prices and its Impact on Indian Stock Market Evidence from BSE Sensex\#
}

\author{
S. Sathyanarayana ${ }^{1 *}$, S. N. Harish ${ }^{2}$ and Sudhindra Gargesha ${ }^{3}$ \\ ${ }^{1}$ Associate Professor, MP Birla Institute of Management, Bangalore - 560001, Karnataka, India; \\ ${ }^{2}$ Associate Professor, REVA University, Bangalore - 560064, India \\ ${ }^{3}$ Joint Director, MP Birla Institute of Management, Bangalore - 560001, Karnataka, India
}

\begin{abstract}
The recent fluctuations in the crudes prices have captured the researcher's attention towards the crucial role that crudes prices play on the economy of any nation. The volatility in crude price has influenced the uncertainty in the price expectation in the countries economy. As majority of the empirical studies support that the crude oil price volatility significantly influences the country's economy and also the stock returns. Therefore, understanding the movement of stock returns is an important issue from the perspective of a developing economy like India. Therefore, it is necessary to identify the variables that drives the stock prices are very important for the market participants and policy makers. The aim of this paper is to investigate the volatility of crude prices and its impact on Indian stock market. For the purpose of the study the data has been collected from Prowess data base for a period from 2006 to 2015 . The collected data has been tested for stationarity by employing ADF test and the length intervals for each variable to run the AIC. Later a linear regression has been run. The volatility of the Sensex has been measured by applying GARCH $(1,1)$ model. The linear regression results show that changes in crudes prices have an impact on Sensex. Apart from that the study concludes that the Crude prices was significant in the volatility of the Sensex and have the competency to transmit shock on Sensex. Therefore, policy makers have to take the movement of the crudes prices while framing the policies that affect the economy at large and stock market in particular. Finally, these results have been compared to the available evidence.
\end{abstract}

Key words: Crude Oil prices, GARCH $(1,1)$, Stationarity, Serial Correlation, Volatility

\section{Introduction}

Oil just like any other commodity is regulated by the simple economics law of demand and supply. The demand for crude oil in an economy is highly related to the economic activities in that country. The crude has a history of booms and bursts and is currently witnessing a sharp fall in the prices. This has been termed as one of the most prominent international macroeconomic development of the past two years. The recent fall in the crude prices can be associated to the following reasons; low demand in many countries due to sluggish economic activities, most particularly in China, has led to sharp drops in crude prices. Further, shale boom in United States surging the production of crude and the major oil producing nations like Saudi Arabia, Iran, Russia etc. have failed to lower the production capacity of fear of losing the market share. Now the colossal crude importing countries like India, European nations and Japan the price decrease is a welcome incentive and provide an opportunity for them to strengthen their fiscal position. Even, the Indian government has taken this energy turmoil as an advantage to reduce the subsidies on fuel consumption and thereby strengthen her fiscal position.

*Email: sathya4u.s@gmail.com

"This is the Revised and modified version of the article, presented in the $6^{\text {th }}$ International Conference on Emerging Trends in Finance, Accounting and Banking, SDMIMD, August 2017. 
Like many other Indian prominent industry, the development of the oil and gas industry began slowly. The origin of this industry can be seen from $19^{\text {th }}$ century, where oil exploration started in Digboi in the state of Assam in 1889. Later the government of India realise the significance of the oil and gas sector for economic growth. Therefore, the Government of India, under the Industrial Policy Resolution of 1954 (IPR), declared that oil and gas sector would be the crux sector industry. Consequential to IPR, 1954, the entire sector was controlled by the state-owned companies. With the discovery of the Cambay and the Bombay offshore basin, the domestic oil production increased remarkably. Therefore, in the 1970s, almost seventy percent of the country's crude requirement was met through domestic production. However, in 1973 the OPEC has decreased crude production and declared an embargo on oil exports to the United States and the Netherlands (the supporters of Israel). After this oil shock, the government of India nationalised this sector. This act of the Indian government force the major international players exit the Indian oil and gas industry. Apart from this, the Indian government-imposed lot of restriction on the pricing and distribution mechanism of oil and gas products in India. Later major determinants like technology, distribution etc. increases the problem of crude sector in India. In the early 90 s the government allowed the MNC's to take part in the bidding process. In 1995, the Government declared the joint venture program with private players. Subsequent to the various reforms taken by the government, the area under oil exploration has increased to about fifty percent. In this movement, RIL was made world's largest gas discoveries in Jamnagar, Gujarat. Further, the sector is witnessing the entry of various multinational companies into India.

A slight fluctuation in International crude prices effects different economies in different manner. In 2014, India was the fourth-largest energy consumer in the globe with oil and gas accounting for thirty-seven per cent of its total energy burning and plays a vital role in affecting decision making for all the other major sectors of the economy. However, this sector has been successful in feeding the rapid growth of the developing economy like India. According to the PPAC, for the year 2014
India produced 37,800 TMT of crude oil accounted for $22 \%$ of its domestic consumption. Therefore, she was forced to import over $75 \%$ of the domestic energy requirement. Currently India has twenty-two refineries out of theses seventeen are PSUs, three private sectors owned and two joint ventures. Under public sector, we have IOC, BPC, and HPC being prominent. However, $\mathrm{RIL}$ is the major company in the private sector.

This current study explores the relationship between changes in crude prices and its impact on Indian stock market. The effect of crude prices on emerging markets has been and intense interest to the market participants. As per Manish (2014), a increase in the crude prices may have a connection on the inflation rate and country's trade balance of the and it leads to adverse effect on foreign reserves. Especially from the perspective of developing economy like India crude prices play a prominent role on the overall inflation of the country. Further, it is a well-known fact that any decline in crude oil prices may impacts positively on inflation and current account deficit. The recent decline in crude prices and its significant impact on the economy needs investigation from the perspective of developing economy like India. In addition, the stock markets are the barometers of any economy and they reflect a small change in the macroeconomic factor, it is very essential in understanding the basic causes of drop in crude prices and its impact on the stock market.

The rest of the paper is divided in different sections as follows: The second section would cover the review of literature and research gap for the current study. The third section describes the objectives of the study, hypothesis to be tested and model for the study, section four discusses the data analysis and inferences of the topic covered and, finally, the fifth section would conclude the results with implications followed by the epilogue that would cover the green pastures.

\section{Literature Review}

Recent volatility in crude market have cropped up interest in the crude prices and its impact on macroeconomic factors such as inflation, exchange rate, employment rate, growth rate and stock returns. There 
is a wide range of literature concentrating of the impact on rise in crude prices and fluctuations in crude prices and its impact of stock market. Huang, Yang, and Juan Lee (2007), and Mork's (1989), investigated the connection between the oil prices changing effect the inflation rate and found a significant relationship between the oil prices and inflation rate. Jones and Kaul (1996), studied the impact of stock markets crude oil shocks by analysing present and near future fluctuations in cash flow in expected returns of the market. They have investigated the developed and regulatory environment economies and found that the crude prices allow to predict stock returns except for England. Hamilton's (1983) analysed the impact of oil price prices in US companies and found reasonable influence by the oil prices. Burbridge and Harrison (1984), Gisser and Goodwin (1986), Cobo-Reyes and Quiros (2005), and, Basher and Sadorsky (2006), have found the same evidence. Aloui et. al., (2008), investigated the effects of crude prices on stock returns and his findings provide an evidence that crude prices play a crucial role in forecasting the stock market behaviour. Sadorsky (1999), examined the relationship between crude price volatility on stock market returns and the economic activity in US by using an unrestricted VAR. The study confirms that both the crude prices and the volatility in crude price play a significant role in affecting economic activity. Jones and Kaul (1992; 1996), found that the crude price movements affect U. S. stock market returns. Miller and Ratti (2009), investigated the long-run association between the crude prices and stock markets by using VECM. They find a long-run association between crude price and stock returns.

Dhaoui and Naceur (2014), found a strong negative association in selected seven countries between oil price and stock market returns. Cong et. al., (2008), tried to explore the relationship between crude oil price shock and Chinese stock market; they did not find statistical evidence for the stated objectives in the Chinese stock market. In a study by Alvarez and Solis (2010), found a statistical support for weak form of efficiency over a wide range of time-scales. Sandorsky (1999) and Papapetru (2001), empirically showed that a crude stock have a negative and significant initial impact on the stock returns. Inayat (2010) investigated the rela- tionship between crude prices and stock performance of European automobile companies. He concluded that the oil is not having a significantly adverse impact on auto returns. However, the high-end car manufacturers have shown volatile in stock returns during the analysis period. Jungwook and Ronald (2008) investigated the impact of crude prices shocks and stock markets in the developed market context and concluded that the crude price shocks account for six percent volatility in stock return.

Maghyereh and Akttam (2004) contradicted the view of Jungwook and Ronald (2008) by using VAR models and concluded that the crude price shocks have no significant impact on index returns. Ono (2011) examined the influence of crude oil prices on BRIC stock markets. He concluded that the stock returns of China, Russia and India have a positive impact and the Brazil stock returns do not show any statistical significance. In an investigation by Ready (2013), concluded that the oil demand shocks correlated positively with stock returns, however, oil supply in the counties has a negative correlation with stock returns. Akomolafe and Danladi (2014), investigated the association between company's stock returns and variations in crude oil returns. They adopted the co-integration and VECM to analyse the relationship. The result proved that the banking sector responds mostly to change in oil price. In an investigation by Kollias et. al., (2011), found the covariance between company returns and oil returns in war time period. Chen (2010), investigated the relationship between high oil prices and its impact on stock market returns by taking S\&P 500 Price Index as proxy. The findings of the study revealed that there is high probability of a bear market emergence as a result of increase in crude prices. Nandha and Faff (2008), studied the short-term relationship between crude prices and thirty-five prominent global industries. The findings of the study revealed that the crude oil prices have a negative impact on all of studied sectors except the oil and gas sector. An empirical study conducted by Perk and Ratti (2008), showed that the increases in crude prices have a negative impact on returns in the developed stock markets. In an investigation by Huang et al. (1996), by using an unrestricted VAR model, found no statistical evidence of an association between 
crude prices and the S\&P500 index. Chen et al. (1986), and Apergis and Miller (2009), reported the similar findings in the developed stock markets.

Bulks of the literature have found the oil price in the international markets has causal on stock returns. For example Hamilton (2000), Hamilton (1983), Loungani (1986), Burbridge and Harrison (1984), Hooker (1996), Gisser and Goodwin (1986), Mork (1989), and Francois and Valerie (2008), have held the similar findings. Awerbuch and Raphael (2006), reported that increase in crude price and volatility in crude decreases economic growth of an economy by increasing inflation. Somoye and Ilo (2008), found that crude oil, inflation and exchange rate helps to determine the stock returns in Nigeria. In an empirical study by Chaudhuri and Daniel (1998), claimed that oil price impacts the stock market in long-run. Ojebiyi and Wilson (2011), found a negative relationship between crude prices and exchange rates. In a study conducted by Evangelia (2001) found the relationship between crude oil prices, debt instrument rates, Greece employment condition, and stock market prices, the study also suggested that the economic activity and employment were affected by changes in crude oil moment. In an investigation by Hidhayathulla and Rafee (2012), proposed a model to demonstrate the relationship between crude price and exchange Rate (by taking Repee and \$). Continuous import of crude leads to increase in demand for dollar and in turn this leads to weaken Rupee value against dollar. Bhunia (2013), pointed out that crude oil price, domestic gold price, stock market index movements and countries exchange rates are integrated in long run in India. Subarna et. al., (2012), examined the comovements of macroeconomic variables such as stock and gold price, exchange rate and the crude price. The result of the study reported that there is a co-integration association between the macroeconomic variables and crude prices. Siddiqui (2014), explored the impact of fluctuation in crude price, foreign exchange rate and foreign private portfolio investment on Pakistan stock markets. This study results revealed that the oil prices, exchange rate and foreign private portfolio investment have positive correlation with stock market returns.
The above studies do not find the conclusive evidence on influence of Crude price on the stock returns. Current study differs due to various following reasons. First, bulk of the literature focus on crude oil prices fluctuations and its impact on macroeconomic variables such as inflation, interest rate, employment rate, forex rate, growth rate etc. However, couple of studies undertaken to examine the association between crude oil returns and the stock returns, which have been studied from the perspective of emerging stock market and oil rich nation's stock market, only a few studies have concentrated on emerging markets like India. Not much empirical studies have been conducted from the Indian stock markets perspective. Therefore, the current study tries to analyse the association between crude returns and its impact on Indian stock returns. Lastly, we examine the crude oil returns volatility and Indian stock returns volatility. For this purpose, we selected Sensex returns as proxy for the stock returns. Most of the studies conducted so far have not given a clear direction between two these two different markets. Therefore, the current study has been undertaken to fill the gap.

\section{Need of Research Design}

\subsection{Objectives of the Study}

H1. To investigate the relationship between crude prices and its impact on the Indian stock market with special reference to Sensex.

2. To examine the volatility of the crude oil returns and the Sensex returns

\subsection{Sampling}

The current study investigates the relationships between crude prices and stock prices in India for the period $1^{\text {st }}$ January 2006 to $31^{\text {st }}$ December 2015 using daily data of adjusted closing prices.

\subsection{Hypothesis of the Study}

$\mathrm{H} 0=$ There is no significant relationship between Crude prices volatility and Sensex volatility 


\subsection{Research Methodology}

In the first phase descriptive statistics have been run to break down the collected data to understand the mean reactions, standard deviation, other applicable insights to find out the outliers and to better comprehend the information. In the second phase the collected data has been tested for unit root by applying ADF test. In the third phase a robust regression has been run and residual diagnostics test like Serial Correlation LM Test and Heteroskedasticity Test: Breusch-Pagan-Godfrey have been conducted. In the fourth phase to investigate the causes of volatility in Sensex GARCH $(1,1)$ model have been run by all the three GARCH $(1,1)$ models viz., Normal GAUSSIAN, Student $t$ Distribution and GED with fix parameters. In the last phase a brief discussion and conclusion have been made.

\subsection{Specification of the Model}

Following linear regression model has been used to test the relation between the Crude price and Sensex.

$$
Y(\text { Sensex Return })=a+b X(\text { Crude })+€
$$

Where,

$\mathrm{Y}=$ Sensex returns

$\mathrm{X}=$ Crude returns

$\mathrm{a}=$ intercept

$b=$ coefficients of crude returns

$\mathrm{C}=$ error component

\section{$\operatorname{GARCH}(1,1)$}

\section{Mean Equation}

$$
\mathrm{SR}=\mathrm{C} 1+\mathrm{C} 2 * \mathrm{CR}+\mathrm{e}
$$

In this case SR (Sensex returns) - is the dependent variable

Crude returns (CR) is the independent variable

$\mathrm{C} 1=$ constant

\section{$\mathrm{C} 2$ is the coefficient}

$\mathrm{e}=\mathrm{is}$ the residual

$$
\begin{aligned}
& \text { Variance equation - this is the GARCH (1,1) Model } \\
& \qquad \mathrm{H}_{\mathrm{t}}=\mathrm{C} 3+\mathrm{C} 4 \mathrm{H}_{\mathrm{t}-1}+\mathrm{C} 5 * \mathrm{e}_{\mathrm{t}-1}^{2}+\mathrm{C} 6 * \mathrm{CR}
\end{aligned}
$$

Here, $\mathbf{H}_{\mathrm{t}}=$ variance of the residual (error term) derived from equation 2. It is also known as current day's variance or volatility of Sensex return

\section{$\mathrm{C} 3=$ constant}

$\mathbf{H}_{\mathrm{t}-1}=$ previous day's residual variance or volatility of Sensex return. It is known as GARCH term

$\mathrm{C} 4$ is the coefficient of $\mathrm{H}_{\mathrm{t}-1}\left(\mathrm{HereH}_{\mathrm{t}-1}\right.$ means one period lag of $\mathrm{H}_{\mathrm{t}}$ )

$\mathbf{H}_{\mathrm{t}}=$ is current day's volatility

$\mathrm{H}_{\mathrm{t}-1}=$ Previous day's volatility (that is today's fluctuations are depend on yesterday's fluctuations) (or today's fluctuations are influenced by yesterday's fluctuations)

$\mathrm{e}^{2}{ }_{\mathrm{t}-1}=$ Previous period's squared residual derived from equation (2). It is also known as previous day's Index return information about volatility, it is ARCH term

Equation 3 is a GARCH $(1,1)$ model, as it has one $\boldsymbol{A R C H}\left(\boldsymbol{e}_{\mathrm{t}-\mathrm{l}}^{2}\right)$ and one $\boldsymbol{G A R C H}\left(\boldsymbol{H}_{\mathrm{t}-\mathrm{l}}\right)$ term, in other words, it refers to first order ARCH term and First order GARCH term. ARCH and GARCH are both internal shocks of the volatility of the dependent variable (they are also known as family shock) that is influencing the Sensex returns.

\section{Data Analysis and Interpretation}

ADF Unit Root Test was conducted at $99 \%, 95 \%$ and $90 \%$ level of significance. Lag length was chosen as per Akaike Information Criterion (AIC). It is evident from the above Table No. 4.1 the unit root was not a problem as the $\mathrm{p}$ value is less than $1 \%$ at level, trend and intercept and at none. 
Table 4.1 Unit Root - Sensex

\begin{tabular}{|l|l|c|c|c|c|c|}
\hline Variables & & ADF Value & $\mathbf{1 \%}$ level & 5\% level & $\mathbf{1 0 \%}$ level & P value \\
\hline \multirow{3}{*}{ Sensex } & Level & -47.60222 & -3.432789 & -2.862503 & -2.567328 & 0.0001 \\
\cline { 2 - 7 } & Trend and Intercept & -47.59441 & -3.961739 & -3.411617 & -3.127679 & 0.0000 \\
\cline { 2 - 7 } & None & -47.58806 & -2.565893 & -1.940951 & -1.616614 & 0.0001 \\
\hline \multirow{3}{*}{ Crude } & Level & -52.82729 & -3.432789 & -2.862503 & -2.567328 & 0.0001 \\
\cline { 2 - 7 } & Trend and Intercept & -52.83901 & -3.961739 & -3.411617 & -3.127679 & 0.0000 \\
\cline { 2 - 7 } & None & -52.83566 & -2.565893 & -1.940951 & -1.616614 & 0.0001 \\
\hline
\end{tabular}

\begin{tabular}{|l|c|c|}
\hline Table 4.2 Descriptive statistics of Crude Price and Returns \\
\hline & Crude Returns & Sensex Return \\
\hline Mean & -0.00014 & 0.00036 \\
\hline Standard Error & 0.000475 & 0.000309 \\
\hline Standard Deviation & 0.0237 & 0.015411 \\
\hline Sample Variance & 0.000562 & 0.000238 \\
\hline Kurtosis & 5.177201 & 8.635765 \\
\hline Skewness & 0.148941 & 0.15738 \\
\hline Minimum & -0.13065 & -0.11604 \\
\hline Maximum & 0.164097 & 0.1599 \\
\hline Sum & -0.3522 & 0.894842 \\
\hline Count & 2485 & 2485 \\
\hline
\end{tabular}

\section{Graph No 4.1}

Graph showing returns and closing price moment of Crude and Sensex
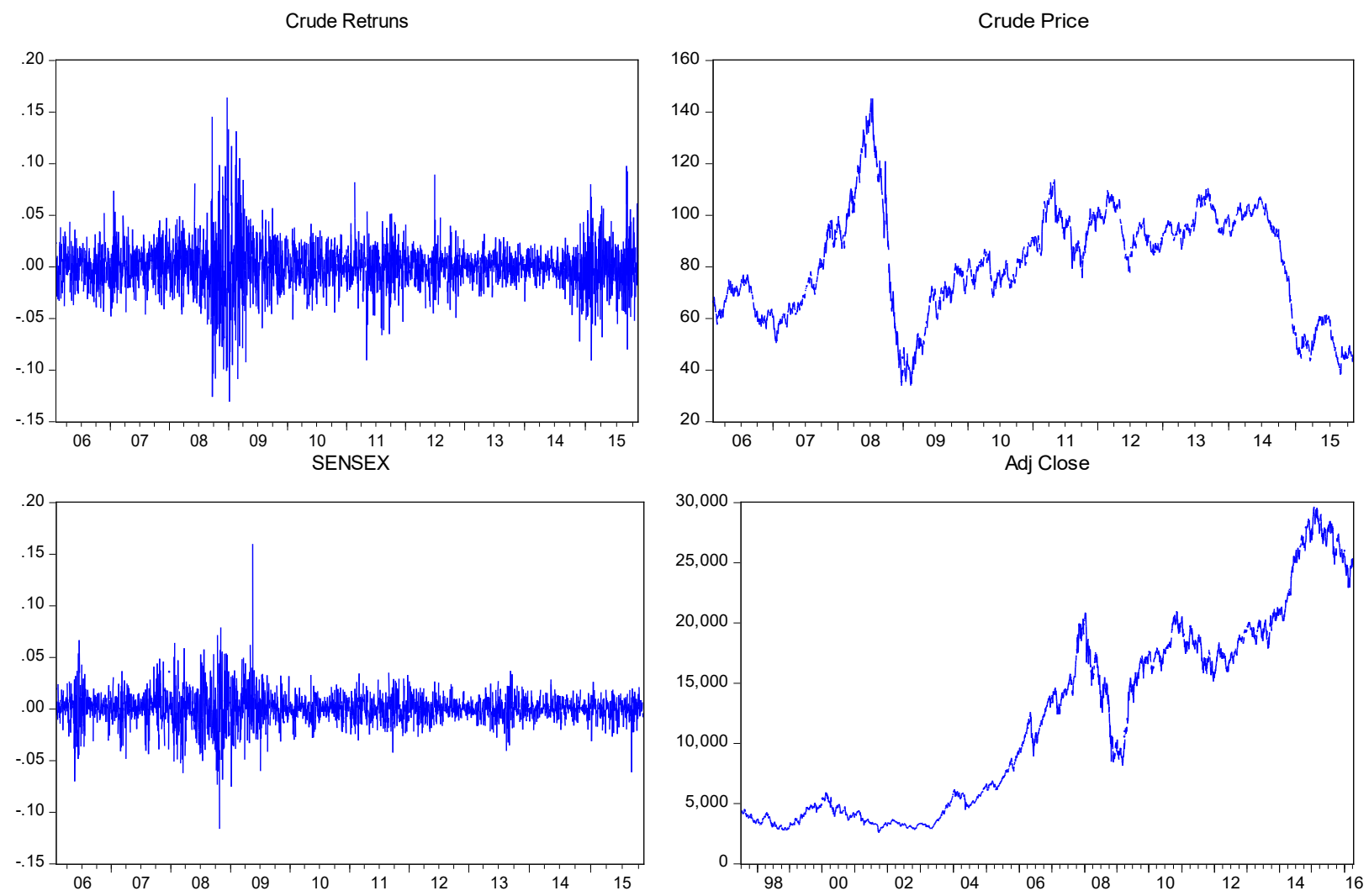
It is evident from the above Table No. 4.2, the mean return of crude for the study period was -0.00014 with a standard deviation of 0.000196 . However, a Sensex mean return for the same period was 0.000428 with a standard deviation of 0.015937 .

Table 4.3 Regression Statistics

\begin{tabular}{|l|l|l|l|l|}
\hline \multicolumn{5}{|l|}{ Dependent Variable: SENSEX } \\
\hline \multicolumn{4}{|l|}{ Method: Least Squares } \\
\hline Variable & Coefficient & Std. Error & t-Statistic & Prob. \\
\hline C & 0.000360 & 0.000302 & 1.193055 & 0.2330 \\
\hline CRUDE & 0.141504 & 0.012733 & 11.11282 & 0.0000 \\
\hline SENSEX (-1) & 0.038731 & 0.019579 & 1.978162 & 0.0480 \\
\hline R-squared & 0.049411 & Mean dependent var & 0.000353 \\
\hline Adjusted R-squared & 0.048644 & S.D. dependent var & 0.015410 \\
\hline S.E. of regression & 0.015030 & \multicolumn{2}{|l|}{ Akaike info criterion } & -5.556277 \\
\hline Sum squared resid & 0.560490 & \multicolumn{2}{|l|}{ Schwarz criterion } & -5.549251 \\
\hline Log likelihood & 6903.896 & \multicolumn{4}{|l|}{ Hannan-Quinn criter. } & -5.553726 \\
\hline F-statistic & 64.47991 & \multicolumn{4}{|l|}{ Durbin-Watson stat } & 2.090061 \\
\hline Prob(F-statistic) & 0.000000 & \multicolumn{5}{|l}{} \\
\hline
\end{tabular}

Standard error is a measures of accuracy estimation of coefficients, it needs to be lower. In the Table No. 4.3 that only the fourth variable (crude) showed a positive coefficient i.e. 0.141504 with a standard error of 0.012733 meaning that crude returns share direct relationship with Sensex returns during the study period. Crude returns were statistically significant at conventional levels of significance $(5 \%)$ with a $t$ value of 11.11282 and $p$ value of 0.000 indicating that there is a significance relationship between crude returns and Sensex returns. Apart from that the R Square 0.049411 indicates that $4.9 \%$ of the variability in the Sensex return, around the sample mean index return, is associated with crude returns indicating that only $4.9 \%$ of the information of sensex returns is predicted by the model, and F-Statistic indicates that the overall fit of the model was good. Even the Durbin-Watson stats indicate that there is no significant positive serial correlation.

\subsection{Residual Diagnostics - Regression Model}

In order to check the fitness of the model the following three residual diagnostics were conducted:
Table 4.4 Breusch-Godfrey Serial Correlation LM Test

\begin{tabular}{|l|l|l|l|}
\hline F-statistic & 1.669709 & Prob. F(2,1492) & 0.1887 \\
\hline Obs*R-squared & 3.340893 & Prob. Chi-Square(2) & 0.1882 \\
\hline
\end{tabular}

It is evident from the above Table No. 4.4 there is no serial correlation in the time series data

One of the major assumption of both linear and multiple regression model is errors are independent from one another meaning that they are uncorrelated. In order to investigate the serial correlation B-S Serial correlation LM test is by forming hypothesis there is no serial correlation in the distribution. The above table result shows that $\mathrm{p}$ value is more than $5 \%$, therefore we cannot reject the null hypothesis.

Table 4.5 Heteroskedasticity Test: Breusch-Pagan-Godfrey

\begin{tabular}{|l|l|l|l|}
\hline F-statistic & 1.167738 & Prob. F(1,1494) & 0.2800 \\
\hline Obs*R-squared & 1.168388 & Prob. Chi-Square(1) & 0.2797 \\
\hline Scaled explained SS & 2.000250 & Prob. Chi-Square(1) & 0.1573 \\
\hline
\end{tabular}

Homoscedasticity test has been conducted with the Null Hypothesis that $H_{0}: \alpha=0$ with the following alternative $H_{1}: \alpha \neq 0$. The $\mathrm{p}$ value is greater than $5 \%$ therefore, this study concludes that the there is no heteroskedasticity in the returns series.

\section{CUSUM Test}

Graph No 4.2 Cusum test results

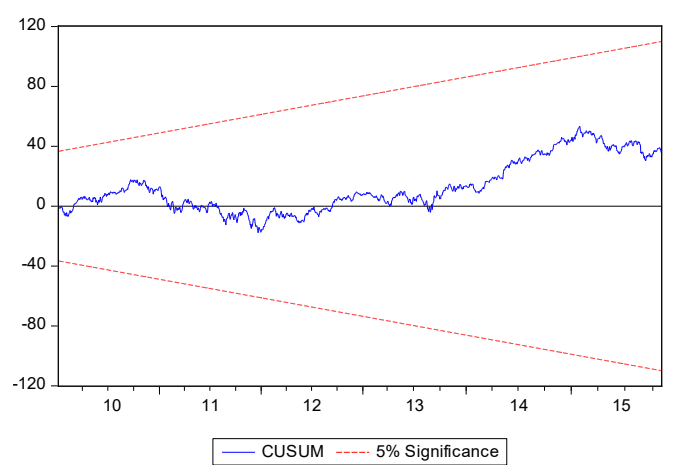

Notes: The boundary straight lines show the critical values at the $5 \%$ level of significance.

The CUSUM test statistic line has the ability to identify small level shifts in the distribution by plotting a 
statistic that integrates present and old data from the movement. The above graph proves the stability in the series. This is support by the results of the above table 4.2 which shows that that the stability of the regression model is good.

\section{GARCH $(1,1)$}

In order to investigate the volatility transmission, the Generalized Autoregressive Conditional Heteroscedasticity $(\mathrm{GARCH}(1,1))$ test was conducted to understand the impact of oil prices on Sensex by taking Sensex as a dependent variable and crude prices has independent variable by using daily time series data covering the period between 2000 and 2015. The GARCH $(1,1)$ was used to capture the main characteristics of time series data, such as stationary by using fat tails and volatility clustering. In addition, the ARCH effects which contradict the random walk concept. For the study purpose all the three GARCH $(1,1)$ models viz., Normal GAUSSIAN, Student t Distribution and GED with fix parameters have been run. The results of the tests (Normal GAUSSIAN, Student t Distribution and GED with fix parameters) for the GARCH (1.1) test are presented in the following Table No.

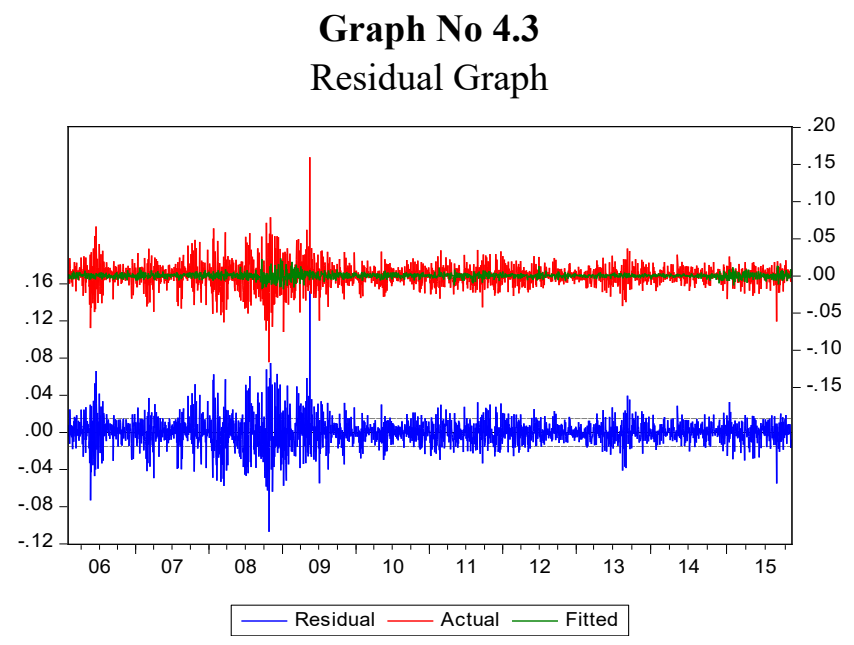

Table 4.6 Arch model Normal distribution.

\begin{tabular}{|l|c|c|c|c||}
\hline \multicolumn{5}{|c||}{ Method: ML - ARCH (Marquardt) - Normal distribution } \\
\hline \hline GARCH $=\mathrm{C}(4)+\mathrm{C}(5)^{\star}$ RESID(-1)^2 $+\mathrm{C}(6)^{\star} \mathrm{GARCH}(-1)$ \\
\hline Variable & Coefficient & Std. Error & z-Statistic & Prob. \\
\hline \hline C & 0.000669 & 0.000212 & 3.156594 & 0.0016 \\
\hline \hline CRUDE & 0.103232 & 0.009654 & 10.69267 & 0.0000 \\
\hline
\end{tabular}

\begin{tabular}{|l|l|l|l|l|}
\hline SENSEX(-1) & 0.050047 & 0.021099 & 2.372018 & 0.0177 \\
\hline \hline \multicolumn{5}{|l|}{ Variance Equation } \\
\hline C & $2.66 \mathrm{E}-06$ & $4.86 \mathrm{E}-07$ & 5.473139 & 0.0000 \\
\hline \hline RESID(-1)^2 & 0.090125 & 0.007557 & 11.92541 & 0.0000 \\
\hline GARCH(-1) & 0.898554 & 0.008385 & 107.1577 & 0.0000 \\
\hline
\end{tabular}

$\begin{aligned} \mathrm{GARCH}= & \mathrm{C}(4)+\mathrm{C}(5) * \operatorname{RESID}(-1)^{2}+ \\ & \mathrm{C}(6) * \operatorname{GARCH}(-1)\end{aligned}$

It is evident from the above table that the crude price shares a positive coefficient with Sensex indicating that it is shares is a direct relationship with crude price. It indicates that an increase in crude prices will lead to an increase of volatility in Sensex.

In the above table no.4.6 the GARCH $(1,1)$ Model shows that, at Normal GAUSSIAN distribution, Student $t$ distribution and GED with fix parameters, the $\mathrm{p}$ value is 0.0000 . Apart from this, the $\mathrm{p}$ value of $\mathrm{ARCH}$ 1 and GARCH 1 are also less than 0.0000 . Hence the null hypothesis that the no volatility caused by crude prices has been rejected.

We can conclude that the Crude prices were significant in the volatility of the Sensex. Apart from that the ARCH 1 and GARCH1 are also significant at one percent level. ARCH and GARCH are both internal shock of the volatility of the Sensex (they are also known as family shock). The independent variable was also significantly influencing the volatility in the Indian stock market meaning that we can reject the Null Hypothesis. Null hypothesis rejection indicates that crude oil prices are significant to affect and have the competency to transmit shock on Sensex.

Residual Diagnostics tests - GARCH 1.1. model.

To investigate the existence of autocorrelation in the residuals Q - statistic test was conducted. The above table presented results accepts the null hypothesis of no auto correlation in the time series data. The above correlogram of squared residuals test results indicate that the residuals are not auto correlated as the $p$ value is greater than five percent at all lags and now the series can be used for hypothesis tests and forecasting. 
Table 4.7 Correlogram of Standardized Residuals - Q-statistics (Normal Gaussian distribution, Student t distribution and GED with fix parameters)

\begin{tabular}{|c|c|c|c|c|c|c|}
\hline & \multicolumn{2}{|c|}{ Normal Gaussian Distribution } & \multicolumn{2}{|c|}{ Student's t distribution } & \multicolumn{2}{|c|}{ GED } \\
\hline & Q-Stat & Prob. values & Q-Stat & Prob. values & Q-Stat & Prob. Values \\
\hline 1 & 0.0132 & 0.909 & 0.0589 & .0 .808 & 0.4133 & 0.520 \\
\hline 2 & 0.2500 & 0.882 & 0.2976 & 0.862 & 0.6296 & 0.730 \\
\hline 3 & 0.3741 & 0.946 & 0.4047 & 0.939 & 0.7226 & 0.868 \\
\hline 4 & 0.5567 & 0.968 & 0.5756 & 0.966 & 0.8755 & 0.928 \\
\hline 5 & 0.8218 & 0.976 & 0.8197 & 0.976 & 1.1017 & 0.954 \\
\hline 6 & 1.8440 & 0.933 & 1.8601 & 0.932 & 2.1605 & 0.904 \\
\hline 7 & 1.9287 & 0.964 & 1.9472 & 0.963 & 2.2393 & 0.945 \\
\hline 8 & 2.6975 & 0.952 & 2.7149 & 0.951 & 3.0328 & 0.932 \\
\hline 9 & 3.7966 & 0.924 & 3.7094 & 0.929 & 3.9669 & 0.914 \\
\hline 10 & 5.5715 & 0.850 & 5.3705 & 0.865 & 5.5593 & 0.851 \\
\hline 11 & 7.1555 & 0.786 & 7.0178 & 0.798 & 7.1975 & 0.783 \\
\hline 12 & 7.8658 & 0.796 & 7.6973 & 0.808 & 7.8543 & 0.796 \\
\hline 13 & 8.0785 & 0.838 & 7.8677 & 0.852 & 7.9733 & 0.845 \\
\hline 14 & 8.0887 & 0.885 & 7.8892 & 0.895 & 8.0184 & 0.888 \\
\hline 15 & 11.343 & 0.728 & 10.963 & 0.755 & 11.031 & 0.750 \\
\hline 16 & 17.633 & 0.346 & 17.491 & 0.355 & 17.848 & 0.333 \\
\hline 17 & 18.494 & 0.358 & 18.255 & 0.373 & 18.481 & 0.359 \\
\hline 18 & 22.023 & 0.231 & 22.082 & 0.228 & 22.569 & 0.208 \\
\hline 19 & 22.442 & 0.263 & 22.482 & 0.261 & 22.940 & 0.240 \\
\hline 20 & 23.273 & 0.276 & 23.314 & 0.274 & 23.744 & 0.254 \\
\hline 21 & 23.373 & 0.324 & 23.417 & 0.322 & 23.848 & 0.300 \\
\hline 22 & 23.407 & 0.379 & 23.462 & 0.376 & 23.908 & 0.352 \\
\hline 23 & 25.796 & 0.311 & 25.971 & 0.302 & 26.507 & 0.278 \\
\hline 24 & 29.904 & 0.188 & 29.977 & 0.186 & 30.370 & 0.173 \\
\hline 25 & 30.068 & 0.222 & 30.169 & 0.218 & 30.597 & 0.203 \\
\hline 26 & 30.070 & 0.265 & 30.172 & 0.261 & 30.602 & 0.243 \\
\hline 27 & 30.564 & 0.289 & 30.771 & 0.281 & 31.284 & 0.260 \\
\hline 28 & 30.567 & 0.337 & 30.772 & 0.327 & 31.284 & 0.305 \\
\hline 29 & 31.331 & 0.350 & 31.541 & 0.340 & 32.060 & 0.317 \\
\hline 30 & 34.668 & 0.255 & 34.958 & 0.244 & 35.509 & 0.225 \\
\hline 31 & 34.885 & 0.288 & 35.180 & 0.277 & 35.731 & 0.256 \\
\hline 32 & 37.610 & 0.228 & 37.902 & 0.218 & 38.466 & 0.200 \\
\hline 33 & 37.880 & 0.256 & 38.157 & 0.246 & 38.709 & 0.228 \\
\hline 34 & 39.935 & 0.223 & 40.147 & 0.216 & 40.625 & 0.202 \\
\hline 35 & 40.186 & 0.251 & 40.465 & 0.242 & 41.003 & 0.224 \\
\hline 36 & 42.346 & 0.216 & 42.717 & 0.205 & 43.351 & 0.186 \\
\hline
\end{tabular}

\subsection{ARCH Effect Test}

To investigate the presence of heteroscedasticity in the distribution of the residuals, an ARCH test was conducted. Results from the ARCH test are depicted in the Table No.
4.8 for all the three parameters. The ARCH test results indicate that there are no ARCH effects in the residuals. In other words, there is no heteroscedasticity in the residuals; thus, the residuals can be said to be homoscedastic. 
Table 4.8 Normal Gaussian distribution, Student's t distribution and GED with fix parameters

\begin{tabular}{|l|l|l|l|}
\hline \multicolumn{4}{|c|}{ Heteroskedasticity Test: ARCH } \\
\hline F-statistic & 1.320693 & Prob. F(1,2481) & 0.2506 \\
\hline Obs*R-squared & 1.321055 & Prob. Chi-Square(1) & 0.2504 \\
\hline \multicolumn{4}{|c|}{ Student's t distribution } \\
\hline \multicolumn{4}{|c|}{ Heteroskedasticity Test: ARCH } \\
\hline F-statistic & 1.453995 & Prob. F(1,2481) & 0.2280 \\
\hline Obs*R-squared & 1.454314 & Prob. Chi-Square(1) & 0.2278 \\
\hline \multicolumn{4}{|c|}{ GED with fix parameters } \\
\hline \multicolumn{4}{|c|}{ Heteroskedasticity Test: ARCH } \\
\hline F-statistic & 1.579903 & Prob. F(1,2481) & 0.2089 \\
\hline Obs*R-squared & 1.580170 & Prob. Chi-Square(1) & 0.2087 \\
\hline
\end{tabular}

\section{Discussion and Conclusion}

The recent fluctuations in the crude prices have captured the economists, policy makers and the researchers attention. Crude oil not only serves as a major source of energy but also act as an important source of raw material for various industrial applications. Further, the energy and transportation cost are linked to the crude oil prices. The crude prices decide the level of inflation and real interest rates. Therefore, it is one of the most demanded commodities across the globe. Small fluctuations in crude prices effects different economies in different manner. These fluctuations in crude prices are called oil shocks. These shocks have an impact on macroeconomic variables of a nation and India in particular, because we depend on crude imports to meet seventy percent of the domestic oil demand. This in turn, results in spending or saving of huge amounts of foreign exchange.

In the current paper, we examine the Indian stock market reaction to the changes in crude oil prices. The empirical study is based on the daily Sensex returns on changes in oil prices over the sample period of $1^{\text {st }}$ January 2006 to $31^{\text {st }}$ December 2015 . The collected data has been investigated for the unit root by employing ADF test. Later a linear regression model has been run to investigate the relationship. In order to enlarge the explanatory power of the computed regression model the researchers have also investigated the volatility factor by running $\operatorname{GARCH}(1,1)$ model to uncover the volatility created by the crude prices fluctuation and its impact on the Sensex movement. The results indicate that the crude oil prices have a major impact on the performance of Indian benchmark BSE Sensex index. The crude price has a positive coefficient which means that Sensex shares a direct relationship with the crude price. It indicates an increase in crude price would cause the Sensex to go up and vice versa and the results are also statistically significant at one percent level. The Durbin Watson Statistic is 2.09 which is indicating the absence of autocorrelation. Therefore, we can conclude that the crude price is the perfect example of macroeconomic factor which can affect the stock market. In the second part of the paper we explored the transmission of volatility and shocks between crude oil price and Sensex. GARCH $(1,1)$ model results also supported the regression model that the independent variable crude price is significant in the volatility of the Sensex returns. Further, the ARCH 1 and GARCH 1 are also significant at conventional 5\% level meaning that they are significantly influencing the volatility in the Indian stock market. Null hypothesis rejection indicates that model results are significant and have the competency to transmit shock on BSE (Sensex). Therefore, the current paper establishes that significant variation in crude prices have a direct influence on stock returns and volatility, particularly countries that are dependent on imports to meet the domestic demand for oil and their stock markets may be prone to crude price shocks. Our results seem to agree with the results of Nidhi and Kirti (2012), Suliman Abdalla (2013), Ugur Ergun and Azizah Ibrahim (2013), Kapil Jain (2013), and contradicts the findings of Oskooe (2011); Miller and Ratti (2009), and Bernanke et al. (1997).

The implications of the current research are that there exists a relationship between crude prices and Sensex. However, the impact of variations in crude oil prices on the economy differs from nation to nation. Further, the volatility of the crude price challenges for policy makers in oil-importing countries like India because crude price is a critical source of energy and input for many industrial applications. The current study reveals that crude prices affects the capital markets. Therefore, the price fluctuations have been an issue of concern to policy makers. Our $\mathrm{R}$ square value (0.049411) indicates that there are many other mac- 
roeconomic variables that have had an influence on stock returns and volatility in Sensex. However, the empirical findings of this study will provide useful information to the market participants who need to understand the effect of fluctuations in crude prices and its impact on stocks and they need to device sound hedging policy to mitigate their risk exposure. The result of the current study is very useful to the various major oil companies whose stocks are traded on Indian stock market. Further, the results of the study is also beneficial to the market participants, who buy or sell or hold the stocks of these companies and wish to find out how the shares of the different companies behave to fluctuations in the oil prices. In the same way, policymakers must pay attention towards the fluctuations in crude prices and its impact on the economy at large and financial markets in particular. They should focus on framing the efficient pricing and distribution policy as oil prices in India is regulated by the state to hedge out the international crude oil price exposure risk.

\subsection{Direction for Further Research}

This study can be extended further by considering more indices such as Nifty Fifty, BSE 100 and other sectorial indices. An extended study should also cover the macro economic variables like interest rate, inflation, growth rate etc. to understand the impact of volatility in oil prices upon these macro-economic variables.

\section{Bibliography}

Alvarez, J. \& Solis, R. (2010). Crude oil market efficiency and modeling: Insights from the multi scaling autocorrelation pattern. Energy Economics, 32(5), 993-1000.

Apergis, N. \&Miller, S. M. (2009). Do structural oil-market shocks affect stock prices? Energy Economics. 31(4), 569-75. crossref

Awerbuch, Shimon, \& Raphael, S. (2006). Exploiting the Oil- GDP Effect to Support Renewables Deployment. Energy Policy, 34(17): 2805-19. crossref

Basher, S. A. \& Sadorsky, P. (2006). Oil Price Risk and Emerging Stock Markets. Global Finance Journal, 17, 224-51. crossref
Bera, A. K., \& Jarque, C. M. (1982). Model specification tests: A simultaneous approach. Journal of Econometrics, 20, 59-82. crossref

Bhunia, A. (2013). Cointegration and causal relationship among crude price, domestic gold price and financial variables an evidence of BSE and NSE. Journal of Contemporary Issues in Business Research, 2(1), 1-10.

Burbridge, J., \& Harrison A. (1984), 'Testing for the effects of oil price rises using vector autoregressions', International Economic Review, 25, 459-84 crossref

Chaudhuri, K. \& Daniel, B.C. (1998). Long-run Equilibrium Real Exchange Rates and Oil Prices. Economics Letters, 58, 231-8. crossref

Chen, N., Roll, R \& Ross, S. A. (1986). Economic forces and the stock market. The Journal of Business, 59(3), 383403.

Cobo-Reyes, R., \& Quiros, G. P. (2005). The Effect of Oil Price on Industrial Production and on Stock Returns. Working Paper 05/18. Departamento de Teoria e Historia Economica, Universidad de Granada.

Cong, R.-G., Wei, Y.-M., Jiao, J.-L., \& Fan, Y. (2008). Relationships between oil price shocks and stock market: An empirical analysis from China. Energy Policy, Elsevier, 36(9), 3544-53. crossref

Gisser, M., \& Goodwin, T. H. (1986). Crude oil and the macro economy: Tests of some popular notions. Journal of Money, Credit and Banking, 18(1), 95-103. crossref

Grorge, H. \& Evangelia, P. (2001). Macroeconomic Influences on the Stock Market. Journal of Economics and Finance, 25(1), 33-49. crossref

Hamilton, J. D. (1983). Oil and the macroeconomy since World War II. The Journal of Political Economy, 91(2), 228-48. crossref

Hidhayathulla, A. \& Rafee, M. (2012). Relationship between Crude oil price and Rupee, Dollar Exchange Rate: An Analysis of Preliminary Evidence. IOSR Journal of Economics and Finance (IOSR-JEF), 3(2), 1-4.

Hooker, M. A. (1996). What Happened to the Oil PriceMacroeconomy Relationship. Journal of Monetary Economics, 38, 195-213. crossref crossref

Huang, R. D., Masulis, R. W. \& Stoll, H. R. (1996). Energy shocks and financial markets. Journal of Futures Markets, 16, 1-27. crossref

Jarque, C. M., \& Bera, A. K. (1987). A test for normality of observations and regression residuals. International Statistical Review, 55, 163-72. crossref 
Jones, C. M., \& Kaul, G. (1996). Oil and the Stock Market. Journal of Finance, 51(2), 463- 491. crossref

Jungwook, P. \& Ronald, A. R. (2008). Oil price shocks and stock markets in the U.S. and 13 European Countries. Energy Economics, 30, p 2587-608.

Kapil, J. (2013). Oil price volatility and its impact on the selected Economic indicators in India. International Journal of Management and Social Sciences Research (IJMSSR), 2(11).

Loungani. (1986). Oil price shocks and the dispersion hypothesis. Review of Economics and Statistics, 58, 5369. https://doi.org/10.2307/1926035

Maghyereh, A. (2004). Oil price shocks and emerging stock markets. A generalized VAR approach. International Journal of Applied Econometrics and Quantitative Studies, 1(2), 27-40.

Miller, J. I., \& Ratti, R. A. (2009). Crude oil and stock markets: Stability, instability, and bubbles. Energy Economics, 31(4), 559-68. crossref

Mork, K. A. (1989). Oil and the Macroeconomy. When Prices Go Up and Down: An Extension of Hamilton's Results. The Journal of Political Economy, 97(3), 740-4. crossref

Nandha, M., \& Faff, R. (2008). Does oil move equity prices? A global view. Energy Economics, 30, 986-97. crossref

Nidhi, S., \& Kirti, K. (2012). Crude oil price velocity and Stock market ripple. IJEMR, 2(7).

Ojebiyi, A. \& and Wilson, D. O. Exchange rate volatility: an analysis of the relationship between the Nigerian
Naira, oil prices and US dollar. Master of International Management.

Papapetrou, E., (2001). Oil price shocks, stock market, economic activity and employment in Greece. Energy Economics, 23, 511-32. crossref

Perk, J., \& Ratti, R. A. (2008). Oil price shocks and stock markets in the US and 13 European countries. Energy Economics, 30, 2587-608. crossref

Ready \& Robert, C. (2013). Oil prices and long-run risk, working paper. Routledge, Bryan R., Duane J. Seppi, and Chester S. Spatt, 2000, Equilibrium forward curves for commodities. The Journal of Finance, 55, 1297-338.

Sadorsky, P. (1999). Oil Price Shocks and Stock Market Activity. Energy Economics, 2, 449-69. crossref

Seyyed, A. P. O. (2011). Oil price shock and stock market in an Oil exporting country. Evidence from causality in mean and variance test. International Conference on Applied Economics. ICOAE 2011. PMid:23393508 PMCid: PMC3562895

Subarna, K. S., \& Ali, H. M. Z. (2012), Co-Movement of Oil, Gold, the US Dollar, and Stocks. Modern Economy, $3,111-7$

Suliman, Z. S. A. (2013). Modelling the impact of oil price fluctuations on the stock returns in an emerging market: the case of Saudi Arabia. Interdisciplinary Journal of Research in Business, 2(10), 10-20.

Ugur, E. \& Azizah, I. (2013). Global energy prices and the behaviour of energy stock price fluctuations. Asian Economic and Financial Review, 3(11):1460-5. 